\title{
Surgical management of stage I and II vulvar cancer:The role of the separated incision
}

\author{
Andrijono, M Farid Aziz, N Kampono
}

\begin{abstract}
Abstrak
Kanker vulva merupakan kanker ginekologi yang kejadiannya relative sedikit. Pasien umumnya datang pada stadium lanjut, terapi radiasi pada stadium lanjut tidak memberi prognosis yang baik. Dua modalitas utama pengobatan kanker vulva yaitu terapi pembedahan dan terapi radiasi. Terapi radiasi dapat dilakukan pula pada stadium awal, tetapi terapi pembedahan dinilai mempunyai beberapa kelebihan, antara lain faktor efek samping pada ovarium/gangguan fungsi reproduksi, faktor higienis pasien dan kemudahan terapi bila terjadi residif. Berbagai variasi teknik pembedahan kanker vulva, antarannya adalah vulvektomi radikal dengan insisi kupu-kupu (VRIK), vulvektomi radikal dengan insisi terpisah (VRIP). Tujuan penelitian adalah melihat keuntungan pembedahan vulvektomi radikal dengan insisi terpisah dibandingkan dengan insisi kupu-kupu dalam hal lamanya pembedahan, penyembuhan luka, kejadian infeksi, lamanya perawatan. Penelitian ini merupakan uji klinik. Selama kurun waktu $1990-2000$ terdapat 15 kasus kanker vulva yang dilakukan pembedahan, 14 kasus stadium II dan 14 kasus dengan histologi karsinoma sel skuamosa dan 1 kasus dengan adenokarsinoma. Lama pembedahan pada VRIP rata-rata 168 menit, lebih singkat dibandingkan VRIK yang mencapai rata-rata 275 menit. Kejadian infeksi pada kelompok VRIP 3 dari 11 kasus (27.27\%) sedangkan pada kelompok VRIK seluruh kasus mengalami infeksi pada luka pembedahan. Kegagalan aproksimasi luka operasi 1 dari 12 kasus ( 9.99\%) sedangkan pada VRIK seluruh kasus mengalami kegagalan sehingga memerlukan pembedahan kosmetik. Lama perawatan pasca bedah kelompok VRIP 12.3 hari sedangkan VRIK 21.5 hari. Dengan demikian pembedahan VRIP lebih kecil komplikasinya dan lebih pendek lama pembedahan dan lebih pendek masa perawatan pasca bedah. (Med J Indones 2003; 12: 103-8)
\end{abstract}

\begin{abstract}
Vulvar cancer is a gynecological cancer whose incidence rate is relatively low. Patients generally were admitted at advanced stage, and radiation therapy at advanced stage does not provide favorable prognosis. Two main modalities in the treatment of vulvar cancer are surgery and radiation therapy. However, radiation can be performed in early stage vulvar cancer but surgery is thought to have more benefits, such as in side effect on the ovary/ reproductive function disorder, patient's hygiene factor, and the ease in performing therapy if recurrence occurs. There are various techniques of vulvar cancer surgery, such as radical vulvectomy with butterfly incision (RVBI) and radical vulvectomy with separated incision (RVSI). The objective of this study was to identify the benefits of radical vulvectomy with separated incision in comparison with radical vulvectomy with butterfly incision in terms of the length of surgery, wound recovery, infection incidence, length of hospital stay. This study was a clinical trial performed during the period of 1990-2000. Fifteen cases of vulvar cancer were found and underwent surgery. Fourteen cases were at stage II and 14 cases were histologically defined as squamous-cell carcinoma and 1 case was adenocarcinoma. The average length of surgery in RVSI was 168 minutes, this was shorter than that in VRBI which reached an average of 275 minutes. The incidence of infection in RVSI group was 3 of 11 cases (27.27\%), while in RVBI group all cases had infection in surgical wound. Failure of surgical wound approximation was 1 of 12 cases (9.99\%), while in RVBI all cases experienced the failure such that cosmetic surgery was required. Length of postoperative care in RVSI group was 12.3 days, while in RVBI 21.5 days. Thus, complications in VRBI were lower, and length of surgery and length of postoperative care were shorter. (Med J Indones 2003; 12: 103-8)
\end{abstract}

Keywords: vulvar cancer, separated incision

Vulvar cancer is one of the gynecological cancers whose incidence rate is relatively low. This cancer

Department of Obstetrics and Gynecology Faculty of Medicine, University of Indonesia/Dr. Cipto Mangunkusumo General Hospital Jakarta, Indonesia ranks last in prevalence among gynecological cancers, and this finding is consistent with the medical records of patients with new vulvar cancer at Dr Cipto Mangunkusumo General Hospital whose incidence ranges between 3 and 4 every year. Since the incidence of this cancer is very low, the experience with the management of vulvar cancer, particularly 
surgical experience, is very limited. This is due to the fact that patients admitted to hospital have been at advanced stage and inoperable. Among modalities of therapy of vulvar cancer are surgery, radiation therapy or chemotherapy. Radiation therapy is the therapy of choice for patients with vulvar cancer at advanced stage; however, further developments show that the results obtained are considered to be more effective if radiation therapy is combined with chemotherapy, which is known as chemoradiation. In addition, vulvar cancer at early stage can be administered radiation therapy, yet the administration of radiation therapy has some obstacles, i.e. the hygiene problem of patient and the greater possibility of therapy failure compared with surgery. For this reason, surgical therapy is the therapy of choice for the cases which are still at early stage and operable. The problem experienced in surgery is the disruption in surgical wound healing. This condition occurs because wide vulvar excision to obtain a free margin of $2 \mathrm{~cm}$ frequently results in disrupted approximation of wound healing. Because of this, plastic surgery is frequently undertaken to overcome the disrupted healing and to enhance the cosmetic value of patient through, among others, skin graft. Nevertheless, the side effect of surgery is milder than that of radiation. To deal with the problem of such disrupted wound healing various modifications of radical vulvectomy, such as radical vulvectomy with separate incision, are attempted. With this separate incision, it is hoped that the better approximation of healing wound can be obtained such that wound healing would be correspondingly better. This study attempted to examine the technique of radical vulvectomy with separate incision and to compare it with radical vulvectomy with butterfly incision. Variables analyzed included length of surgery, postoperative administration of blood transfusion, infection of surgical wound, length of surgical wound recovery, length of hospital stay, and tumor-free incision edge.

\section{METHODS}

This study was a cohort trial, and the study samples were patients with stage I and stage II vulvar cancers without contraindication for surgery, and patients were willing to undergo surgery. Variables evaluated were length of surgery, blood transfusion, incidence of wound infection, recovery of surgical wound, length of hospital stay, tumor-free incision edge. The results of the study were compared with those of vulvectomy surgery with butterfly incision performed before 1990 .

\section{Surgical technique}

Radical vulvectomy with separate incision: Surgery was performed with separate incision between radical vulvectomy incision and inguinal lymphadenectomy incision. If the incision was wide, plastic surgery would be performed with $\mathrm{Z}$ incision. The incision was started with transversal incision above the symphisis pubis, continued with dissection to perform lymphadenectomy of inguinal lymphatic gland, superficial femoral gland and the right and left profound femoral glands. The closure of incision wounds was performed with intracutaneous suture. Surgery was continued with radical vulvectomy incision separate from transversal incision; urethra would be protected if it was not affected by tumor, and incision reached the clitoris. The surgical areas of lymphadenectomy and vulvectomy were related under the skin, and the removal of gland was achieved through vulvar incision such that the surrounding tissue was involved. The closure of vulvar incision wounds was done with intracutaneous suture, and a drain was inserted from the inguinal region up to the vulva.

Radical vulvectomy with butterfly incision: Surgery was performed with butterfly incision. The incision covered the region of inguinal and vulvae lymphatic gland.

Postoperative mobilization was performed in four days after surgery. If patient received adjuvant radiation because of the attendant risk factor, radiation would be administered after recovery of surgical wounds.

The study was conducted from 1990 to 2000 at $\mathrm{Dr}$ Cipto Mangunkusumo General Hospital, Jakarta.

\section{RESULTS}

During the period of study (1990-2000) there were 11 cases of vulvar cancer undergoing surgery.

It was interesting to note that the cases of vulvar cancer studied were of young age, i.e. below 65 years. This condition was markedly different from the age characteristics of patients with vulvar cancer in Europe which generally were above 65 years. 
Table 1. Characteristics of patients

\begin{tabular}{lcc}
\hline \multicolumn{1}{c}{ Variables } & $\begin{array}{c}\text { RVSI } \\
\text { Group }\end{array}$ & $\begin{array}{c}\text { RVBI } \\
\text { Group }\end{array}$ \\
\hline Age ( mean ) & 44.2 years & 47.3 years \\
\hline Histopathological type & & \\
- Squamous-cell carcinoma & 10 & 4 \\
- Adenocarcinoma & 1 & \\
Stage & & \\
- Stage I ( T1 ) & 1 & 0 \\
- Stage II ( T2 ) & 10 & 4 \\
\hline
\end{tabular}

Table 2. Surgical variables

\begin{tabular}{lcc}
\hline \multicolumn{1}{c}{ Variables } & $\begin{array}{c}\text { RVSI } \\
\text { Group }\end{array}$ & $\begin{array}{c}\text { RVBI } \\
\text { Group }\end{array}$ \\
\hline Metastasis to lymph nodes & 2 & 4 \\
Number of lymph nodes & 19,7 & - \\
Approximation failure & 1 & 4 \\
Incidence of infection & & \\
- Infection (+) & 3 & 4 \\
- Infection (-) & 9 & 0 \\
Length of surgery & 168 minutes & 275 minutes \\
Blood transfusion & & \\
- Blood transfusion (+) & 2 cases & 0 \\
- Blood transfusion (-) & 9 cases & 4 \\
Length of hospital stay & 12.3 & 21.5 \\
\hline
\end{tabular}

\section{Tumor-free mass}

Tumor-free margin is relatively difficult to analyze. Of the cases studied, only eight cases with separated incision could be observed. One case experienced one-year pregnancy after radical vulvectomy, and the baby was delivered through cesarean section. As many as four cases were still controlled to date (66.8 months), and no recurrence was discovered. Three cases were still controlled to dated (18 months), one case experienced recurrence in the $27^{\text {th }}$ month, and provided appropriate response to radiation administration.

\section{DISCUSSION}

Vulvar cancer is a gynecological cancer whose incidence rate was low in Indonesia. This situation is quite different from that in Europe in which the incidence rate of this cancer is reasonably high. However, with the improvement of early detection methods in vulvar cancer the incidence rate of this cancer has been lowered to the stage of pre-cancerous lesion. The most frequent cause of vulvar cancer is associated with HPV infection, such that early detection of vulvar cancer is almost identical with early detection for cervical cancer of the uterus. Colposcopic examination accompanied by biopsy is a very good method; this early identification will cut off the link of incidence of vulvar cancer. This condition is quite different from that in Indonesia in which patients with vulvar cancer were admitted to hospital at advanced stage such that the therapies administered did not yield satisfactory results. At early stage, frequently vulvar cancer produces itching symptoms and hot sensation at the vulva. These symptoms were frequently not considered to be a problem by patients or even by the examining physician. The change of color on skin surface in skin texture will be evident when it is closely examined. The factors of patient's attention and physician's alertness will be of enormous help in diagnosing vulvar cancer at pre-cancerous state or early state. Another distinguishing factor is that patients with vulvar cancer in Indonesia were relatively younger than those in European countries.

In European countries, patients with vulvar cancer are generally above 65 years of age. Our study, however, demonstrated that the average patients' age was relatively younger, i.e. 44.2 years. Even one patient was relatively very young such that she became pregnant following radical vulvectomy. Radiation therapy is a therapy of choice for the advanced stage vulvar cancer; however, the administration of radiation therapy at advanced state has several weaknesses. In addition, the outcome of radiation therapy at early stage was found by several investigators to be lower than that of surgery. The weaknesses of radiation therapy have been studied by GOG who demonstrated that radiation dose received by the lymph node at femoral blood arteries was not optimal because the radiation at a dose of 5000 cGy only reached a depth of $3 \mathrm{~cm}$. On the other hand, based on the study performed it showed that the average depth of femoral arteries was $6.1 \mathrm{~cm}$, thus the reach of therapy was only $18 \%$.

The development of surgical therapy in vulvar cancer has so far been in favor of more conservative intervention. In tumor with T1, radical excision surgery could be performed, accompanied by ipsilateral excision of lymph node. Recurrence rate of radical vulvectomy in TI vulvar cancer was approximately $7.2 \%$, while in radical excision $6.3 \%$. These findings 
showed no difference in recurrence rate in both surgical techniques. Thus, radical local excision becomes the choice in surgery for $\mathrm{T} 1$ vulvar cancer.

Of the cases in our study, there was only one case with $\mathrm{T} 1$, and the rest were the cases with $\mathrm{T} 2$, such that the appropriate surgical therapy in our cases was radical vulvectomy. In T2 tumors or higher, the option pursued was radical vulvectomy. Two basic surgical approaches in radical vulvectomy can be pursued, i.e.:

1. The en block approach ( butterfly incision )

2. The separate incision approach

The en block surgical approach (butterfly incision) has been developed at the educational center of Dr Cipto Mangunkusumo General Hospital/ Faculty of Medicine University of Indonesia prior to 1988. However, after that period we attempted to develop separated incision approach. We noted several weaknesses in butterfly incision, and it proved that with separated incision some weaknesses in relative butterfly incision are reduced to a minimum. The problem frequently encountered in radical vulvectomy is the closure of wide wound. The closure of wide wound can be performed with full-thickness skin flaps or gracilis myocutaneous graft.

During the period of study, 11 cases of vulvar cancer underwent radical vulvectomy with separated incision (RVSI group). On the other hand, radical vulvectomy with butterfly incision was performed in four cases (RVBI group). The four cases with butterfly incision underwent surgery during the period prior to 1998 , while radical vulvectomy with separated incision was performed after 1988. All this time, we only performed radical surgery with local incision in the cases of local recurrence.

Histopathological type of squamous-cell carcinoma was the most frequently found type, while other histopathological types included adenocarcinoma, basal cell carcinoma or melanoma, verrucouous carcinoma and vulvar sarcomas were relatively rare.

Metastasis of vulvar cancer generally occurred through direct extension, lymphatic embolization and hematogenous spread. Metastasis occurring through lymphatic embolization generally directed to femoral lymph node and involvement of the inguinal nodes, but some authors found involvement to femoral lymph node without involvement of the inguinal nodes. The overall incidence of lymph node metastases is reported to be approximately $30 \%$. Metastases to the pelvic node are uncommon, the overall reported frequency being approximately $9 \%$. The incidence of lymph node metastases relation to lesion size is as follow : $1 \mathrm{~cm}$ or less, $5 \% ; 1$ to $2 \mathrm{~cm}$, $16 \%$; 2 to $4 \mathrm{~cm}, 33 \%$; greater than $4 \mathrm{~cm}, 53 \%$. In our cases undergoing radical vulvectomy with separated incision, metastasis to gland was found in $16.6 \%$ of the cases. This percentage did not differ significantly from that reported by some investigators. The number of glands removed was one of the parameters for adequacy of surgery. If the removal of gland did not meet the required number, it means that the surgery performed was not radical such it would be better to administer adjuvant therapy. Approximately there are 10 lymph nodes in the group of superficial and profound lymph nodes at each side. Thus, when lymph node excision was performed, the number of glands removed would be 20 . In radical vulvectomy performed the average number of gland removal we found was 19.7. This figure showed that more than $90 \%$ of glands were removed, indicating an adequate number of gland removal.

\section{Postoperative complication}

The major immediate morbidity is related to groin wound infection, necrosis, and breakdown. This incidence had been reported in up to $80 \%$ of patients having an en block operation. This situation did not differ from the results we found, i.e. all cases of four cases undergoing butterfly surgery suffered from that complication. On the other hand, the incidence of breakdown in the cases of separate incision could lower the incidence of breakdown up to $14 \%$. Of the cases undergoing surgery with separate incision, the incidence of breakdown was found in one case $(8.3 \%)$. This disruption in healing process occurred in incision wound at the juncture above the urethra. This lowering was due to the fact that the closure of wide surgical wound was overcome by full-thickness skin flap ( $z$ plasty). Overall, the healing of surgical wound in separate incision technique was better than that in butterfly incision. Disruption of wound healing would affect the patient's length of hospital stay. Based on the data of patients undergoing surgery it appeared that the length of hospital stay for patients undergoing radical vulvectomy with separate incision was shorter than that of butterfly incision.

Mobilization in surgery with separated incision could be performed on day four or five of hospital stay, and 
the average hospital stay could reach 12 days with surgical wound already healed.

Length of surgery, administration of blood transfusion during surgery and postoperative incidence of infections appeared to be better in surgery with separated incision. Bleeding during radical vulvectomy frequently occurred. This condition occurred because the vulva was abundant with blood vessels, and these blood vessels intercommunicate with one another. With appropriate dissection technique, the bleeding can be minimized. In addition, appropriate dissection technique would be able to visualize blood vessels properly.

It is difficult for us to analyze our patient survival completely, since three cases were lost from follow up, only eight cases could be analyzed. Four cases survived without tumor up to more than five years. These four cases did not experience metastasis to lymph node. Cases that did not experience other metastasis were three surviving cases without tumor; however, up to this writing they have not reached five-year follow up. Three cases were lost from observation because they did not follow up and their tumor condition was unknown. Radiation therapy administered was primary radiation in advanced stage vulvar cancer; however, radiation therapy was also administered as adjuvant therapy and in recurrent cases. One case experiencing recurrence during observation provided appropriate response with radiation therapy. Of interest is that once case of vulvar carcinoma recurred in one year after radiation therapy, and radical vulvectomy with separate incision was performed with the outcome of freetumor incision edge. Nineteen months later the tumor had recurrence, and radical vulvectomy with $z$ plasty was performed and a free-tumor incision edge was again achieved. Imaging examination with $\mathrm{CT}$ in 12 months after surgery in Indonesia and Germany showed no suspicion of recurrent lesion, but 14 months later a recurrence in the incision wound was found and radiation was administered. Response to the radiation was appropriate; however, nine months after radiation the patient died from recurrence at the vertebra and cerebrum. Of the cases we analyzed, two cases experienced metastasis and both died before reaching five years. This finding was consistent with the results found by several authors, i.e. a survival rate of $43.7 \%$ in the cases with metastasis to lymph nodes. One case of recurrent vulvar carcinoma after radiation was found with metastasis in two years. This case underwent radical vulvectomy radical with separate incision and tumor-free incision edge was achieved. Recurrence occurred in the posterior vaginal wall and the tumor infiltrated to the rectum 17 months after surgery. Furthermore, posterior exenteration was performed with free-tumor incision edge. However, the patient died eight months after exenteration from unexplained causes.

Based on the data obtained, we could not make comparison between radical vulvectomy with separate incision versus radical vulvectomy with butterfly incision because of the limited number of cases. However, these results can still serve as a guideline because they showed that there are several factors more beneficial in radical vulvectomy with separate incision compared with radical vulvectomy with butterfly incision.

Surgery of vulvar cancer is currently performed with node sentinel detection by using patent blue. By injecting patent blue intra tumor, lymph current will be visualized, and patent blue accompanied by radioactive will make it easier to understand the spread of cancer to lymph node. With this technique, the invaded lymph will be easily identified and excision can be performed. Techniques of lymph node excision have also been developed further, and one of these is surgery through laparoscopy. The administration of lipolysis will facilitate the visualization of lymph nodes such that the removal of the nodes will be easier and this could be achieved with the use of laparoscopy. Metastasis to lymph nodes is one of the most determining prognosis factors, and the spread on one side of lymph node indicates a favorable prognosis. However, the spread to more than two and bilateral glands will reduce survival rate up to $20 \%$. In view of the results found from the patients undergoing radical vulvectomy, it appears that surgery with separate incision is more beneficial because of shorter length of surgery, less bleeding, less incidence of infection, and shorter length of surgical wound healing as well as shorter length of hospital stay.

\section{CONCLUSION}

Radical vulvectomy with separate incision has an average length of surgery of 168 minutes, blood transfusion at $22.22 \%$, infection incidence $33.33 \%$, 
incidence of wound disapproximation $9.99 \%$, and length of hospital stay 12.3 days.

\section{REFERENCES}

1. Hacker NF, Nieberg RK, Berek JS, Lagasse LD. Superficially invasive vulvar cancer with nodal metastases. Gynecol Oncol 1983;15:65-77

2. Podczaski E, Sexton M, Kaminski P, Singapuri K, Sorosky J, Larson $\mathrm{J}$ et al. Recurrent carcinoma of the vulva after conservative treatment for " microinvasive" disease. Gynecol Oncol 1990;39:65-68

3. Way S. Carcinoma of the vulva. Am J Obstet Gynecol 1960;79:692-699

4. Hacker NF, Berek JS. Vulva. In: Haskell CM,ed. Cancer treatment, $3^{\text {rd }}$ ed. Philadelphia: WB Saunders, 1990:351361

5. van der Velden J, Hacker NF. Update on vulvar carcinoma. In: Rothenberg ML, ed. Gynecologic Oncology : controversies and new development. Boston : Kluwer, 1994: 101-119
6. Jones RW, Rowan DM. Vulvar intraepithelial neoplasia III : a clinical study of the outcome of 113 cases with relation to the later development of invasive vulvar carcinoma. Obstet Gynecol 1994;84:741-745

7. Morley GW. Infiltrative carcinoma of the vulva: results of surgical treatment. Am J Obstet Gynecol 1976;124:874880

8. Abitbol MM. Carcinoma of the vulva: improvements in the surgical approach. Am J Obstet Gynecol 1973; 117:483-489

9. Byron RL, Mishell DR, Yonemoto RH. The surgical treatment of invasive carcinoma of the vulva. Surg Gynecol Obstet 1965;121:1243-1249

10. Hacker NF, Leuchter RS, Berek JS, Castaldo TW, Lagasse LD. Radical vulvectomy and bilateral inguinal lymphadenectomy through separated groin incisions. Obstet Gynecol 1981;58:574-579

11. Hacker NF. Vulvar cancer. In: Berek JS, Hacker NF ed. Practical Gynecologic Oncology. Philadelphia: Lippincott Williams \& Wilkins, 2000; 553-596

12. N, Triaspolitica. "Mengenal Penyakit Kanker, Jenis, Gejala, Penyebab Berikut Pengobatan Kanker." Mau Nanya Dong Dok. N.p, 20 June 2017. Web. 28 June 2017. $<$ https://nanyadongdok.blogspot.com/2017/06/mengenalpenyakit-kangker-jenis-gejala.html>. 
